\title{
KEUNGGULAN KOMPARATIF USAHATANI PADI \\ PADA BERBAGAI POLA AGROEKOSISTEM DI KABUPATEN MEMPAWAH
}

\section{ADI SUYATNO ${ }^{1}$, MASYHURI ${ }^{2}$, JANGKUNG HANDOYO MULYO ${ }^{2}$, IRHAM ${ }^{2}$}

\author{
${ }^{1}$ Mahasiswa Pascasarjana Fakultas Pertanian UGM dan Staf Pengajar \\ Program Studi Agribisnis Fakultas Pertanian Universitas Tanjungpura \\ ${ }^{2}$ Staf Pengajar Program Studi Agribisnis Fakultas Pertanian \\ Universitas Gadjah Mada
}

\begin{abstract}
This research was conducted in the District of Mempawah, which is in the region of West Kalimantan and borders with neighboring countries (Malaysia), which of course has special characteristics, especially from the aspect of international trade, so that the comparative advantage of paddy associated with aspects of international trade, need to be examined. This study used a survey method, with 183 sample, where the number of samples of each pattern of agroecosystem isirrigation pattern has 55 samples, tidal patterns has 42 samples, rainfedpatterns has46samples and dry land patterns has 40 samples. The method of analysis in this study used the concept of DRC (Domestic Resource Cost). The results showed comparative advantage as indicated by the average value of the DRC is Rp 2,429, - This value indicates that the cost of domestic resources for the value to produce rice, can save foreign exchange worth US \$ 1. DRCR average of 0,24 which means rice farming has a comparative advantage $(<1)$. Irrigation schemes have the highest levels of comparative advantage and the dry land pattern has the lowest level of comparative advantage. DRCR shows that rice is still cheaper economically to be produced in the country compared with imports from other countries. The implications of this conclusion is that the spur policy (increase) in rice production in the District of Mempawah still favorable compared to the expense of foreign exchange to import the commodity from other countries.
\end{abstract}

Keywords: comparative advantage, Pattern Agroecosystems, Domestic Resource Cost

\section{PENDAHULUAN}

Kabupaten Mempawah merupakan salah satu kabupaten di Kalimantan Barat dan merupakan salah satu sentra produksi serta wilayah pengembangan komoditas padi. Dilihat dari aspek biofisik, zona ini lebih cocok untuk pengembangan komoditas padi dibandingkan dengan di kabupaten lain. Produktivitas padi, di wilayah Provinsi Kalimantan Barat saat ini masih relatif rendah jika dibandingkan dengan daerah lain di Indonesia, terutama Jawa, Sumatera dan Sulawesi, namun demikian masih memiliki potensi dan peluang untuk dikembangkan.

Pada tahun 2013 produksi padi di Kalimantan Barat sebesar 1.571.127 ton atau mengalami peningkatan 20,85 persen dibandingkan dengan tahun 2012 yang 
sebesar 1.300 .100 ton. Peningkatan tersebut karena adanya peningkatan luas panen 15,36 persen, dari 427.798 ha menjadi 493.502 ha dan peningkatan produktivitas sebesar 4,77 persen dari 30,39 kw/ha menjadi 31,84 kw/ha. Produksi padi sawah memberikan kontribusi yang dominan terhadap produksi padi di Kalimantan Barat. Tahun 2013 dari total produksi padi Kalimantan Barat sekitar 84,21 persen berasal dari padi sawah, dan sisanya sebesar 15,79 persen dari padi ladang. Sedangkan tahun 2013, kontribusi padi sawah meningkat menjadi 88,92 persen dan 11,08 persen dari padi ladang (Badan Pusat Statistik, 2013).

Menurut Badan Pusat Statistik (2013), dengan data tahun 2012, produksi gabah kering giling (GKG) sebesar 1.300 .100 ton, dengan angka konversi $63 \%$, maka setara dengan 819.063 ton beras. Berdasarkan rata-rata kebutuhan beras $139,15 \mathrm{~kg}$ per kapita per tahun, konsumsi beras masyarakat Kalimantan Barat adalah sebesar 591.264 ton beras, sehingga masih terdapat surplus. Apabila dilihat produksi nasional pada tahun yang sama, yaitu sebesar 69,05 juta ton, maka provinsi ini memberikan kontribusi produksi sekitar $2 \%$ terhadap produksi nasional.

Meskipun secara resmi terdapat surplus beras di Kalimantan Barat, namun beras yang didatangkan dari luar pulau, terutama dari Jawa, melalui Perdagangan Antar Pulau (PAP) juga cukup besar. Dalam lima tahun terakhir jumlah bongkar beras di PT Pelindo Kalimantan Barat mencapai 54.694 ton, dan rata-rata tumbuh $13,69 \%$ per tahun. Besarnya PAP beras ke Kalimantan Barat dapat dianggap sebagai peluang untuk memacu produksi beras Kalimantan Barat, baik dari segi kuantitas maupun kualitas.

Kinerja tanaman padi di Kabupaten Mempawah (luas panen, produktivitas dan produksi) selama hampir 30 tahun (1971 s/d 2011) tumbuh positif. Luas panen dan produktivitas rata-rata pertumbuhannya 0,85 persen per tahun, sedangkan kinerja produksi rata-rata pertumbuhannya 0,72 persen. Dilihat data tersebut tampak bahwa kinerja tanaman padi belum optimal. Produksi padi Kabupaten Mempawah adalah sebesar 63.410 ton, yang berarti sekitar $5 \%$ dari produksi Kalimantan Barat, yang pada tahun yang sama adalah sebesar 1.300.100 ton GKG (Badan Pusat Statistik, 2012).

Kabupaten Mempawah berada di wilayah Kalimantan Barat yang berbatasan langsung dengan negara tetangga (Malaysia) yang tentu saja memilki karakteristik khusus, terutama dari aspek perdagangan internasional, sehingga keunggulan komparatif komoditas ini terkait dengan aspek perdagangan internasional ini juga perlu dikaji. Uraian di atas menunjukkan perlunya penelitian mengenai efisiensi dan efisiensi dari aspek perdagangan internasional. Dengan memperhatikan permasalahan terkait dengan usaha tani padi di Kabupaten Mempawah, tujuan penelitian adalah untuk mengetahui keunggulan komparatif usahatani padi pada berbagai pola agroekosistem.

\section{METODOLOGI PENELITIAN}

Metode yang digunakan dalam penelitian adalah metode survey. Penelitian ini dilaksanakan di wilayah Kabupaten Mempawah. Lokasi penelitian ditentukan secara sengaja (purposive) dengan pertimbangan lokasi tersebut memiliki pola agroekosistem usahatani padi yang lengkap. Pada lokasi penelitian tersebut dipilih secara sengaja (purposive) empat kecamatan yang mewakili salah satu pola agroekosistem. Terdapat beberapa pola agroekosistem padi di 
Kabupaten Mempawah, meliputi padi lahan sawah irigasi, tadah hujan, rawa pasang surut dan lahan kering.

Pengumpulan data primer dilakukan dengan teknik wawancara mengunakan daftar pertanyaan terstruktur. Pengambilan sampel dilakukan berjenjang (mulai dari berdasarkan wilayah kecamatan, desa, pola usahatani dan sampel petani masing-masing desa). Pada lokasi penelitian dipilih secara sengaja (purposive) empat kecamatan, yaitu Kecamatan Sadaniang, Kecamatan Anjongan, Kecamatan Toho dan Kecamatan Segedong, yang setiap kecamatan mewakili salah satu pola agroekosistem. Metode pemilihan desa sampel dilakukan secara sengaja (purposive), sedangkan penentuan sampel responden dengan metode simple random sampling. Desa-desa sampel terdiri dari Desa Peniti Dalam (Kecamatan Segedong untuk pola pasang surut), Desa Terap (Kecamatan Toho untuk pola Tadah Hujan), Desa Anjungan Melancar (Kecamatan Anjongan untuk pola irigasi) dan Desa Sekabuk (Kecamatan Sadaniang untuk pola lahan kering). Pada penelitian ini diambil 183 sampel penelitian, dengan sampel masing-masing pola agroekosistem adalah pola irigasi 55 sampel, pola pasang surut 42 sampel, pola tadah hujan 46 sampel dan pola lahan kering 40 sampel.

Metode analisis pada penelitian ini digunakan konsep DRC (Domestic Resource Cost). Tower (1992) mengatakan bahwa DRC sering digunakan sebagai alat analisis biaya manfaat, untuk mengevaluasi biaya dari keijakan proteksi dalam rangka melindungi usaha yang ada di dalam negeri. Harga-harga finansial merupakan titik awal dalam analisa. Selanjutnya harga finansial disesuaikan kedalam harga bayangan (shadow price) dan hasil analisisnya merupakan analisis ekonomi. Menurut Gitinger (1986), apabila harga pasar (sebagai nilai finansial) setiap barang atau jasa dirubah untuk secara lebih dekat menggambarkan biaya oportunitas (sebagai nilai ekonomi) terhadap masyarakat, maka nilai yang baru tersebut adalah harga bayangan (shadow price).

Menurut Rachman (1997) penentuan DRC dapat diawali dari konsep Net Social Profitability (NSP) yaitu pendapatan atau kerugian bersih dari suatu aktifitas ekonomi apabila seluruh masukan (input) dan keluaran (output) dinilai dalam biaya peluang sosial dan seluruh pengaruh eksternalitas dari kegiatan tersebut diperhitungkan. Selanjutnya Gray dkk (1992) mengatakan bahwa, nilai ekonomi dari input maupun output tersebut di atas merupakan komponen yang digunakan untuk menghitung nilai DRC (Domestic Resource Cost), dengan cara sebagai berikut :

DRC $=\frac{\sum_{\mathrm{s}=2}^{\mathrm{m}} \mathrm{FSj} \mathrm{Vs}+\mathrm{Ej}}{(\mathrm{Uj}-\mathrm{mj}-\mathrm{rj})}=\frac{\mathrm{BDj}+\mathrm{Ej}}{\mathrm{Pj}-\mathrm{BTj}}$

Sehingga :

DRC $=\frac{B D j+E j}{N T j}=\frac{B D j+E j}{P j-B T j}$


Keterangan :

$\mathrm{BD}=$ biaya komponen domestik

$\mathrm{P} \quad=$ penerimaan

BT = biaya komponen asing

NT = nilai tambah yang diperoleh dari aktivitas tersebut

$\mathrm{E} \quad=$ eksternalitas yang ditimbulkan oleh aktivitas $\mathrm{j}$

Persamaan memperlihatkan bahwa DRC merupakan besarnya biaya sumberdaya domestik yang dikeluarkan untuk memperoleh atau menghemat nilai tambah satu satuan devisa dan dinyatakan dalam satuan Rp/US\$. Nilai Domestic Resource Cost Ratio (DRCR) yang merupakan ratio antara DRC dengan besarnya harga bayangan nilai tukar uang $(\mathrm{Vj})$ sebagai berikut :

DRCR $=\frac{\mathrm{DRC}}{\mathrm{Vj}}$

Keterangan :
DRCR : Domestic Resource Cost Ratio
DRC : Domestic Resource Cost
$\mathrm{Vj} \quad$ : Harga Bayangan Nilai Tukar Uang

Langkah-langkah untuk menghitung nilai ekonomi dari nilai finansial adalah sebagai berikut :

1. Identifikasi terhadap input dan output usahatani ke dalam jenis-jenis barang sebagai berikut : Barang import, Barang eksport, Barang pengganti import, Barang eksport yang dialihkan, Barang yang diperdagangkan secara tidak langsung, Barang yang tidak diperdagangkan

2. Identifikasi input dan output usahatani yang terkait dengan pembayaran transfer langsung (pajak dan subsidi) dan pengambilan data sekunder yang terkait dengan masalah ini

3. Perhitungan nilai c.i.f dan f.o.b dari input dan output usahatani yang termasuk dalam barang yang diperdagangkan serta pengambilan data sekunder yang terkait dengan masalah ini

4. Perhitungan nilai tukar bayangan dan atau pengambilan data sekunder yang terkait dengan perhitungan ini

5. Perhitungan nilai finansial terhadap biaya dan penerimaan usahatani berdasarkan data primer.

6. Penyesuaian nilai finansial terhadap nilai ekonomi biaya dan penerimaan usahatani berdasarkan penyesuaian nilai-nilai barang-barang tersebut di atas

7. Perhitungan nilai eksternalitas pengembangan tanaman pangan dan atau pengambilan data sekunder yang relevan (kerugian akibat erosi sebagai dampak pengusahaan tanaman pangan)

8. Pengelompokan nilai-nilai hasil perhitungan tersebut ke dalam dua katagori yaitu :
a) Nilai sekarang dari pada biaya dalam mata uang domestik untuk merealisasikan penghematan devisa
b) Nilai sekarang daripada penghematan devisa neto

9. Perhitungan Biaya Sumber Domestik (DRC) 
Penetapan harga bayangan dilakukan untuk beberapa komponen input dan output sebagai berikut :

\section{a. Nilai Tukar Uang}

Harga bayangan dari nilai tukar rupiah terhadap dolar dengan menggunakan rumus :

$\mathrm{SER}=\mathrm{OER} / \mathrm{SCF}$

Keterangan :

SER $\quad=$ Nilai tukar uang bayangan

OER = Nilai tukar uang resmi

$\mathrm{SCF} \quad=$ Faktor konversi bahan baku

SCF diperoleh dengan rumus :

$$
S C F=\frac{\mathrm{M}+\mathrm{X}}{(\mathrm{M}+\mathrm{Tm})+(\mathrm{X}-\mathrm{Tx})}
$$

Keterangan :

$\begin{array}{ll}\mathrm{SCF} & =\text { Faktor konversi bahan baku } \\ \mathrm{M} & =\text { Nilai impor }(\mathrm{Rp}) \\ \mathrm{X} & =\text { Nilai ekspor }(\mathrm{Rp}) \\ \mathrm{Tm} & =\text { Pajak impor }(\mathrm{Rp}) \\ \mathrm{Tx} & =\text { Pajak ekspor }(\mathrm{Rp})\end{array}$

\section{b. Output}

Output dalam penelitian ini adalah beras. Harga bayangan dari beras berdasarkan c.i.f, karena komoditas yang diperdagangkan. Untuk menghitung harga bayangan digunakan harga cif ditambah biaya-biaya tata niaga.

\section{c. Pupuk}

Pupuk yang digunakan pada usahatani padi ini adalah pupuk kimia. Pupuk kimia terdiri dari urea, TSP, NPK dan $\mathrm{KCl}$. Untuk menghitung harga bayangan digunakan harga cif ditambah biaya tata niaga.

\section{d. Lahan}

Lahan ternasuk dalam barang tidak diperdagangkan, maka harga yang digunakan adalah biaya oportunitas (nilai production foregone) dari lahan yaitu nilai produksi lahan yang hilang akibat penggunaan untuk usahatani padi.

\section{e. Tenaga kerja}

Oleh karena tenaga kerja termasuk barang tidak diperdagangkan maka upah tenaga kerja yang digunakan adalah biaya oportunitas ( nilai production foregone) dari tenaga yaitu nilai yang diterima oleh tenaga tersebut apabila tidak bekerja mengusahakan usahatani padi.

\section{HASIL DAN PEMBAHASAN}

Analisis keunggulan komparatif usahatani padi, dilakukan terhadap berbagai pola agroekosistem dari beberapa lokasi kecamatan. Analisis keunggulan komparatif usahatani komoditas padi dimaksudkan untuk mengetahui apakah pengusahaan padi secara ekonomi memiliki keunggulan komparatif, baik pada pasar domestik maupun pasar internasional. Hasil analisis komparatif dapat menunjukkan apakah pengusahaan dari usahatani padi tersebut dapat menghasilkan penghematan devisa yang menguntungkan atau tidak. Apabila ongkos dari sumberdaya domestik yang digunakan untuk memproduksi padi lebih lebih rendah dibandingkan dengan devisa yang dapat dihemat dari kegiatan 
tersebut, maka berarti kegiatan tersebut memiliki keunggulan komparatif atau sebaliknya.

Analisis komparatif merupakan analisis yang melibatkan perhitunganperhitungan ekonomi yang didasarkan dari analisis finansial. Oleh karena itu, sebelum dapat melakukan analisis komparatif, terlebih dahulu dilakukan analisis finansial mengenai biaya-biaya dan penerimaan usahatani. Untuk memudahkan analisis dan agar uraian hasil analisis dapat bersifat runtut, maka analisis ini dimulai dari analisis biaya dan pendapatan usahatani secara finansial, dan setelah itu baru dilakukan analisis penyesuaian nilai finansial ke dalam nilai ekonomi dan yang terakhir dilakukan analisis keunggulan komparatif.

Analisis komparatip dimaksudkan untuk mengetahui apakah sumberdaya domestik cukup efisien untuk menghasilkan suatu produk padi (beras) di dalam negeri. Pendekatan yang dilakukan adalah dengan menggunakan nilai Domestic Resource Cost (DRC) dan Domestic Resource Cost Ratio (DRCR). Untuk menghitung nilai-nilai tersebut terlebih dahulu dilakukan penyesuaianpenyesuaian nilai-nilai finansial baik terhadap komponen output maupun komponen input menjadi nilai ekonomi.

Untuk barang-barang yang diperdagangkan penyesuaiannya meliputi tahap-tahap sebagai berikut :

a) Ditentukan besarnya harga perbatasan (bagi barang impor dengan harga c.i.f dan barang ekspor dengan harga f.o.b). Oleh karena produk ini dianggap sebagai barang pengganti impor dan beberapa komponen input dianggap barang impor, maka yang digunakan dalam analisis ini adalah harga cif di pelabuhan.

b) Harga perbatasan tersebut kemudian dikonversikan menjadi nilai-nilai ekonomi dengan memasukan biaya-biaya bongkar muat pelabuhan dan biaya-biaya pengangkutan domestik. Biaya pengangkutan domestik terdiri dari biaya angkut lokal dari pelabuhan ke pedagang besar dan biaya angkut lokal dari lokasi usahatani ke pedagang besar. meliputi :

Penyesuaian barang-barang yang tidak diperdagangkan pada penelitian ini

a) Penilaian sewa tanah, nilai harga bayangannya dihitung dengan membagi besarnya sewa tanah yang berlaku di lokasi dengan the opportunity cost of capital (Kadariah, 1988).

b) Penilaian tenaga kerja, nilai harga bayangannya dihitung dengan cara mencari jumlah hari sibuk petani untuk melakukan usahatani dalam satu tahun, kemudian mengalikannya dengan tingkat upah yang berlaku di lokasi dan membaginya dengan jumlah hari dalam satu tahun (Kadariah, 1988)..

Langkah lain dalam melakukan penyesuaian nilai finansial menjadi nilai ekonomi adalah menentukan shadow exchange rate. Penentuan nilai ini dilakukan dengan menggunakan rumus :

SER $=$ OER/SCF

Keterangan :

SER = Nilai tukar uang bayangan

OER $\quad=$ Nilai tukar uang resmi

SCF $\quad=$ Faktor konversi bahan baku

$\mathrm{SCF}$ diperoleh dengan rumus : 


$$
S C F=\frac{M+X}{(M+T m)+(x-T x)}
$$

Keterangan :

\begin{tabular}{|c|c|}
\hline $\mathrm{SCF}$ & $=$ Faktor konversi bahan baku \\
\hline $\mathrm{M}$ & $=$ Nilai impor $(\mathrm{Rp})$ \\
\hline $\mathrm{X}$ & $=$ Nilai ekspor $(\mathrm{Rp})$ \\
\hline $\mathrm{Tm}$ & $=$ Pajak impor $(\mathrm{Rp})$ \\
\hline Tx & $=$ Pajak ekspor $(\mathrm{Rp})$ \\
\hline
\end{tabular}

Hasil perhitungan nilai tukar bayangan berdasarkan formula tersebut dapat dilihat pada tabel 1. Hasil penyesuaian nilai ekonomi dari nilai finansial ini kemudian digunakan untuk menghitung nilai DRC dan DRCR. Caranya adalah dengan membandingkan nilai biaya sumber daya domestik dengan nilai komponen asing (yang masing-masing sudah dalam bentuk harga ekonomi).

Tabel 1. Perhitungan Nilai Tukar Bayangan (Shadow Exchange Rate)

\begin{tabular}{lr}
\hline Uraian & Nilai \\
\hline Nilai Ekspor (Jutaan Rupiah) & 2.190 .840 .000 \\
Nilai Impor (Jutaan Rupiah) & 2.239 .560 .000 \\
Pajak Ekspor (Jutaan Rupiah) & 17.609 .000 \\
Pajak Impor (Jutaan Rupiah) & 30.812 .000 \\
SFR & 0.989 \\
OER (Rupiah) & 11.834 \\
SER=OER/SFR (Rupiah) & 11.706 \\
\hline
\end{tabular}

Sumber : Hasil Perhitungan dan Data BPS, 2013.

Hasil analisis harga bayangan dapat dilihat pada tabel 2. Analisis keunggulan komparatif menghasilkan nilai DRC rata-rata $\mathrm{Rp} 2.429$,- Nilai ini menunjukkan bahwa dengan biaya sumber daya dalam negeri sebesar nilai tersebut untuk memproduksi padi, telah dapat menghemat devisa senilai US\$ 1 . Nilai ini kemudian dibagi dengan kurs rupiah terhadap dolar, dan ditemukan nilai DRCR rata-rata 0,24 (Tabel 3).

Tabel 2. Penentuan Harga Bayangan Output dan Input

\begin{tabular}{llr}
\hline Jenis Output dan Input & \multicolumn{1}{c}{ Penentuan Harga Bayangan } & Harga Bayangan \\
\hline Padi $(\mathrm{Rp} / \mathrm{kg})$ & CIF + Biaya Tataniaga & 3.945 \\
Sewa Lahan (Rp/ha) & Sewa Lahan/Tingkat Bunga Modal & 110.500 \\
Benih (Rp/kg) & Harga Pasar & 3.945 \\
Tenaga Kerja (Rp/HOK) & Upah Riil x Hari Sibuk & 25.093 \\
Pupuk Urea (Rp/kg) & CIF + Biaya Tataniaga & 3.459 \\
Pupuk TSP $(\mathrm{Rp} / \mathrm{kg})$ & CIF + Biaya Tataniaga & 2.506 \\
Pupuk KCl $(\mathrm{Rp} / \mathrm{kg})$ & CIF + Biaya Tataniaga & 3.680 \\
Pupuk NPK (Rp/kg) & CIF + Biaya Tataniaga & 4.709 \\
Herbisida (Rp/lt) & CIF + Biaya Tataniaga & 49.339 \\
Insektisida $(\mathrm{Rp} / \mathrm{lt})$ & CIF + Biaya Tataniaga & 130.321 \\
\hline
\end{tabular}

Sumber : Hasil Analisis Data Primer

Nilai DRCR kurang dari satu artinya pengusahaan komoditas ini memiliki keunggulan kompatratif. Pada berbagai pola, semakin kecil (kurang dari satu) artinya semakin tinggi tingkat keunggulan komparatifnya. Dengan demikian pola irigasi memiliki tingkat keunggulan komparatif tertinggi dan pola lahan kering memiliki tingkat keunggulan komparatif terendah (Tabel 3). 
Tabel 3. Keunggulan Komparatif Usahatani Padi pada Berbagai Agroekosistem

\begin{tabular}{lr}
\multicolumn{1}{c}{$\begin{array}{c}\text { Pola } \\
\text { Agroekosistem }\end{array}$} & \multicolumn{2}{c}{$\begin{array}{c}\text { Keunggulan } \\
\text { Komparatif }\end{array}$} \\
\hline Lahan Kering & 0.35 \\
\hline Pasang Surut & 0.23 \\
\hline Tadah Hujan & 0.21 \\
\hline Irigasi & 0.18 \\
\hline
\end{tabular}

Sumber: Analisis Data Primer

Nilai DRC dan DRCR tersebut di atas menunjukkan bahwa padi, masih lebih murah secara ekonomi untuk diproduksi di dalam negeri dibandingkan dengan mengimpor dari negara lain. Implikasi dari kesimpulan ini adalah bahwa kebijakan memacu (meningkatkan) produksi padi di wilayah penelitian tetap masih menguntungkan dibandingkan dengan mengorbankan devisa untuk mengimpor komoditi tersebut dari negara lain. Walaupun masih diperlukan biayabiaya untuk kegiatan-kegiatan memacu produksi padi tersebut, namun toleransi nilai DRC dan DRCR tersebut masih mengisyaratkan bahwa kegiatan memacu produksi dalam negeri masih menguntungkan karena nilai DRC masih cukup jauh dibawah nilai kurs rupiah terhadap dolar yang berlaku saat ini dan nilai DRCR masih berada cukup jauh di bawah satu.

Hasil penelitian ini hampir sama dengan beberapa hasil penelitian di daerah lain. Beberapa hasil penelitian yang sama, menunjukkan bahwa komoditas padi masih memiliki keunggulan komparatif untuk diusahakan. Menurut Saptana (2009) bahwa walaupun padi masih memiliki keunggulan komparatif, komoditas tanaman pangan terutama padi semakin rendah dari waktu ke waktu dan rentan terhadap perubahan eksternal. Sedangkan hasil penelitian Antriyandarti dkk (2012) menunjukkan, keunggulan komparatif berupa nilai DRCR komoditas padi di Jawa Tengah adalah sebesar 0,53 yang berarti masih memiliki keunggulan komparatif. Hasil-hasil tersebut didukung juga olah hasil penelitian Mantau dkk (2014) di Sumatera Utara yang menunjukkan bahwa keunggulan komparatif komoditas padi yang ditunjukkan dengan nilai DRCR di wilayah tersebut adalah sebesar 0,68, yang berarti juga masih memiliki keunggulan komparatif.

Dengan cara melihat nilai-nilai ekonomi komponen dalam negeri yang harus dikorbankan untuk menghasilkan produk komoditas padi di atas, maka dapat diketahui beberapa kenyataan yang mendukung hasil analisis tersebut. Komponen tenaga kerja misalnya, upah bayangan menunjukkan nilai yang lebih kecil dari nilai upah secara finansial. Hal ini menunjukkan bahwa sebenarnya walaupun tingkat upah yang berlaku di lokasi cukup tinggi, tetapi pada dasarnya permintaan terhadap tenaga kerja untuk melakukan kegiatan usahatani juga relatif kecil sehingga nilai oportunitas dari upah tersebut menjadi rendah. Penyebabnya adalah karena curahan tenaga kerja untuk melakukan kegiatan usahatani tidak penuh sepanjang tahun, tetapi ada waktu sibuk dan ada waktu senggangnya, sedangkan permintaan tenaga kerja di luar sektor pertanian cukup rendah.

Faktor eksternalitas dalam analisis ini masih diabaikan, namun demikian secara deskriptif disini dapat diungkapkan bahwa faktor tersebut dalam pembentukan nilai DRC berada pada posisi sebagai pembilang, sehingga apabila eksternalitas ini menambah biaya sumberdaya domestik (karena eksternalitas negatip), maka berarti faktor eksternalitas akan meningkatkan nilai DRC. Apabila dilihat dari nilai DRC dan DRCR yang berada pada toleransi yang cukup jauh dari 
batas nilai kritis ( yaitu sebesar kurs rupiah terhadap dolar untuk nilai DRC dan sebesar satu untuk nilai DRCR) maka mengabaikan nilai eksternalitas dalam analisis ini kiranya tidak akan merubah nilai DRC dan DRCR tersebut secara signifikan. Hal ini juga didukung oleh pertimbangan bahwa faktor eksternalitas dari pengusahaan tanaman pangan yang paling menonjol umumnya adalah erosi tanah. Namun demikian nilai ini umumnya sangat kecil karena lokasi kajian bertopografi datar atau tingkat kemiringannya rendah. Lagi pula apabila dibandingkan dengan kondisi lahan tanpa tanaman penutup tanah maka penanaman tanaman pangan justru mengurangi terjadinya erosi. Sebaliknya apabila eksternalitas positip maka yang terjadi justru akan lebih memperkuat hasil analisis ini.

Hasil analisis keunggulan komparatip menunjukkan bahwa secara keseluruhan di lokasi penelitian, menunjukkan nilai DRC (Domestic Resource Cost) yang lebih rendah dari nilai kurs rupiah terhadap dolar dan nilai DRCR (Domestic Resource Cost Ratio) yang lebih kecil dari satu. Hal ini menunjukkan bahwa sumber daya domestik untuk memproduksikan komoditi tersebut cukup rendah dibandingkan dengan devisa yang dapat dihemat dari kegiatan produksi tersebut. Implikasi dari hasil analisis ini adalah bahwa kebijakan memacu peningkatan dan usahatani produksi beberapa tanaman pangan yang menjadi perhatian disini akan lebih menguntungkan secara ekonomi dibandingkan dengan kebijakan impor dari luar negeri (daerah). Walaupun masih diperlukan biayabiaya untuk kegiatan-kegiatan memacu produksi tanaman pangan tersebut, namun toleransi nilai DRC dan DRCR tersebut masih mengisyaratkan bahwa kegiatan memacu produksi dalam negeri masih menguntungkan karena nilai DRC masih cukup jauh dibawah nilai kurs rupiah terhadap dolar yang berlaku saat ini dan nilai DRCR masih berada cukup jauh di bawah satu.

Hasil analisis keunggulan komparatip menunjukkan biaya sumber daya dalam negeri dapat menghemat devisa yang bernilai lebih besar dari biaya tersebut. Dengan demikian padi (beras) masih lebih murah secara ekonomi untuk diproduksi di dalam negeri dibandingkan dengan mengimpor dari negara lain. Kebijakan memacu (meningkatkan) produksi padi di wilayah penelitian lebih menguntungkan dibandingkan dengan mengorbankan devisa untuk mengimpor komoditi tersebut dari negara lain.

\section{KESIMPULAN}

1. Keunggulan komparatip yang ditunjukkan oleh nilai DRC rata-rata adalah Rp 2.429,- Nilai ini menunjukkan bahwa dengan biaya sumber daya dalam negeri sebesar nilai tersebut untuk memproduksi padi, telah dapat menghemat devisa senilai US\$1. Nilai DRCR rata-rata 0,24 yang berarti usahatani padi memiliki keunggulan komparatif. Pola irigasi memiliki tingkat keunggulan komparatif tertinggi dan pola lahan kering memiliki tingkat keunggulan komparatif terendah.

2. Nilai DRCR hasil menelitian ini menunjukkan bahwa beras masih lebih murah secara ekonomi untuk diproduksi di dalam negeri dibandingkan dengan mengimpor dari negara lain. Implikasi dari kesimpulan ini adalah bahwa kebijakan memacu (meningkatkan) produksi padi di wilayah penelitian masih menguntungkan dibandingkan dengan mengorbankan devisa untuk mengimpor komoditi tersebut dari negara lain. 


\section{IMPLIKASI KEBIJAKAN}

Nilai DRCR adalah perhitungan penghematan devisa atas produksi barang diperdagangkan dengan sumberdaya domestik. Hasil perhitungannya menunjukkan kebijakan memacu (meningkatkan) produksi padi di wilayah penelitian masih menguntungkan dibandingkan dengan mengorbankan devisa untuk mengimpor komoditi tersebut dari negara lain. Namun demikian produksi barang yang diperdagangkan (tradeable) memerlukan kebijakan pemerintah untuk melindungi kegiatan produksi dalam negeri. Sekarang ini tingkat proteksi efektif cukup memberikan perlindungan terhadap produsen beras (petani). Namun studi empiris di lapangan menunjukkan bahwa harga pupuk banyak tidak sesuai dengan harga subsidi karena adanya kelangkaan pupuk di lapangan. Hal ini akan mengakibatkan biaya produksi yang relatif tinggi di tingkat petani yang selanjutnya akan menurunkan keunggulan komparatif (daya saing) dan mengakibatkan proteksi maupun kebijakan tarif menjadi tidak efektif lagi. Oleh karena itu diperlukan control dan pengawasan terhadap tataniaga input di lapangan.

\section{DAFTAR PUSTAKA}

Antriyandarti E, S.W. Ani, M Ferichani. (2012). Pengembangan Kawasan Agribisnis Perberasan Propinsi Jawa Tengah Sebagai Upaya Menjaga Kedaulatan Pangan Program Studi Agribisnis, Fakultas Pertanian, Universitas Sebelas Maret Surakarta.

Badan Pusat Statistik. 2012. Berita Resmi Statistik. BPS Kalimantan Barat. Pontianak.

Badan Pusat Statistik. 2013. Berita Resmi Statistik. BPS Kalimantan Barat. Pontianak.

Gittinger. J.P. 1986. Analisis Ekonomi Proyek-Proyek Pertanian. UI Press. Jakarta.

Gray. C., R. Simanjuntak, B.L.K. Sabur, P.F.L. Mospaitella, dan R.C.G. Vorley. 1992. Pengantar Evaluasi Proyek. Gramedia Pustaka Utama. Jakarta.

Kadariah. 1988. Evaluasi Proyek, Analisa Ekonomis. Lembaga Penerbit Fakultas Ekonomi Universitas Indonesia. Jakarta.

Mantau Z, Harianto, N Nuriantono. 2014. Analisis Keunggulan Kompetitif pada Usahatani Padi Sawah di Bolaang Mongondow Provinsi Sulawesi Utara. Journal of Economics and International Finance.

Rachman, B. 1997. Penerapan Analisis Keunggulan Kompetitip dan Keunggulan Komparatip dalam Pengembangan Usahatani Tanaman Pangan (Padi, Jagung dan kacang Tanah) di Propinsi Jambi. Makalah Disampaikan pada Acara Pelatihan Apresiasi Metodologi Delineasi Zona Agroekologi. Kerja sama IPB dan ARMP II Bogor. 
Saptana. 2009. Keunggulan Komparatif-Kompetitif Dan Strategi Kemitraan. Pusat Penelitian Dan Pengembangan Sosial Ekonomi Pertanian Badan Litbang Pertanian, Departemen Pertanian RI.

Tower E. 1992. Domestic Resource Cost. Journal of International Economic. Integration 7 (1), 20-44. 